\title{
Implementation of The Open Jackson Queuing Network to Reduce Waiting Time
}

\author{
Monike Febriyani Faris ${ }^{1}$, Yuniar Farida ${ }^{2}$, Dian C. R. Novitasari ${ }^{3}$, \\ Nurissaidah Ulinnuha ${ }^{4}$, Moh. Hafiyusholeh ${ }^{5}$ \\ ${ }^{1}$ UIN Sunan Ampel Surabaya, monikefebriyani@gmail.com \\ ${ }^{2}$ UIN Sunan Ampel Surabaya, yuniar_farida@ uinsby.ac.id \\ ${ }^{3}$ UIN Sunan Ampel Surabaya, diancrini@uinsby.ac.id \\ ${ }^{4}$ UIN Sunan Ampel Surabaya, nuris.ulinnuha@uinsby.ac.id \\ ${ }^{5}$ UIN Sunan Ampel Surabaya, hafiyusholeh@uinsby.ac.id
}

doi: https://doi.org/10.15642/mantik.2020.6.2.83-92

\begin{abstract}
Abstrak. Menunggu cukup lama untuk mendapatkan pelayanan menjadi suatu hal yang umum dalam pelayanan rumah sakit. Semakin banyak pasien yang menunggu, semakin banyak pasien yang pelayanannya tertunda, sehingga waktu menunggu semakin lama. Dalam proses pelayanan kesehatan suatu rumah sakit, seorang pasien akan mengantri beberapa kali di lebih dari satu antrian dalam instalasi rawat jalan rumah sakit. Penelitian ini menggunakan studi kasus pada sistem antrian instalasi rawat jalan Rumah Sakit, yang bertujuan untuk untuk meminimalisir waktu tunggu dan panjang antrian tiap workstation dengan menerapkan model jaringan antrian Jackson terbuka. Workstation yang diteliti adalah workstation registrasi, prekonsultasi dan konsultasi poli jantung hingga farmasi. Pengumpulan data dilakukan selama 6 hari menghitung jumlah kedatangan dan keberangkatan setiap titik dengan interval 5 menit. Dengan menerapkan model jaringan antrian Jackson terbuka, diperoleh rekomendasi kepada pihak rumah sakit untuk menambah pegawai di titik registrasi menjadi sebanyak 4 loket, titik prekonsultasi poli jantung menjadi sebanyak 3 perawat dan 4 dokter sedangkan untuk farmasi menjadi sebanyak 7 pegawai. Dengan penambahan personel tersebut, total waktu tunggu pasien dalam system antrian menjadi kurang lebih 12 menit/pasien. Sehingga model antrian ini akan mengurangi waktu tunggu dalam system antrian yang semula ratarata $108 \mathrm{menit} / \mathrm{pasien}$.
\end{abstract}

Kata kunci: Antrian; Jaringan antrian Jackson terbuka; Workstation

Abstract. Waiting for service is a common thing in-hospital services. The more patients are waiting, the service delay increases, so waiting time in the queue gets longer. In health care in a hospital, a patient will queue several times in more than one queue in a hospital outpatient installation. The case study in this research is the queue system in the hospital's outpatient treatment, implementing an open Jackson queueing network to minimize waiting time. The workstations examined in this study were the registration, pre-consultation, and cardiology poly consultation, and pharmacy. The data is carried out for six days, counting the number of arrivals and departures with each point at intervals of 5 minutes. Applying the Jackson open queue network model, a recommendation was obtained for the hospital to increase employees' numbers. The registration workstation must have four servers; a poly cardiology workstation had three nurses and four doctors, while for pharmacy, had seven employees. With this personnel's addition, patients' total waiting time in the queuing system is approximately 12 minutes/patient. So, it can reduce waiting times in the queueing system that was initially 108 minutes/patient.

Keywords: Queue; An open Jackson queueing network; Workstation

\footnotetext{
How to cite: M. Febriyani Faris, Y. Farida, D. Candra, N. Ulinnuha, and M. Hafiyusholeh,

"Implementation of The Open Jackson Queuing Network to Reduce Waiting Time”, J. Mat. Mantik, vol.

6, no. 2, pp. 83-92, October 2020.
} 


\section{Introduction}

Cardiovascular is a type of disease related to the heart and blood vessels. Based on WHO data from all deaths globally, 17.9 million people died due to cardiovascular disease, with $85 \%$ of these deaths caused by heart attacks [1]. More deaths are caused by heart attacks, making the Ministry of Health always urges the public to do periodic health checks. Currently, almost all hospitals have cardiology poly, as in the Hospital Sidoarjo.

The Hospital of Sidoarjo has many types of polyclinic in outpatient installations. Cardiology poly was rarely deserted every day. Too many patients make a lot of queues so that patients have to wait long. Long queues occur not only in cardiology poly but also at the point of registration and hospital pharmacy. The length of the queue can make the quality of hospital services less useful.

The queuing system is a set of individuals, servers, and a rule that regulates the arrival of individuals and services [2]. The queuing system is the process of birth-death of the population consisting of individuals waiting to be served and being served [3]. There are three components in the queue system: population arrival, queue, and service facilities [4] [5].

One solution to overcome long queues is implementing a queuing network model that can estimate the actual queue situation to be analyzed. A queueing network is a group workstation where individuals can move from one workstation to another workstation. Implementing the queuing model can estimate the length of service time; therefore, implementing the queuing model can be identified and minimized queues [6].

There are two types of queue networks, open and closed queue network. In the available queue network, individuals who enter the queue network system can come from inside or outside the queue system, and patients can exit the queue network system [7]. The outpatient installation queue system of the hospital has an open queue network characteristic. A patient can come from outside or in the queuing system, and patients can get out of the queuing network system.

Several queueing network models, including Feedforward Queueing Network, Gordon-Newell Queueing Network, BCMP Queueing Network, and Jackson Queueing Network. Feedforward Queueing Network is the most straightforward queueing network where the queueing system is not branched and feedforward. Gordon-Newell Queueing Network is a closed queueing network with service distribution using exponential distribution [8]. BCMP Queueing Network is a queueing network used for open, closed, or mixed queueing network with service discipline can be Last Come First Serve (LCFS) [7].

The Jackson queueing network is a queue where individuals can move from one workstation to another workstation before leaving the system. The individual arrives at the workstation in the form of Poisson distribution, which has queue discipline First Come First Serve (FCFS) and service time of a workstation in the form of exponential distribution [9] [10]. Patient transfer is the probability of patient movement to the next workstation after being served at the previous workstation with certain services [11]. The Jackson queue network has a continuous nature in each workstation where for each queue is independent so that they can analyze each workstation separately [12]. The Jackson Queueing Network has two types, open and closed queues. In an open queue network, individuals who enter the queue network system can come from inside or outside the queuing system, and patients can exit the queuing network system if they have finished receiving the service. Open queue networks have been extensively studied by Burke (1969), who reviewed three workstations [13]. As for the network, Jackson closed is known as the Gordon-Newell Queueing Network [8]. This research will apply the Open Jackson Queueing Network, as shown in Figure 1. 


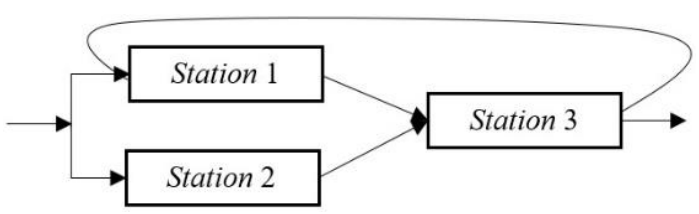

Figure 1. Open Jackson Queuing Network

One of several studies related to the Open Jackson Queueing Network application is the research with the title "On the Application of the Open Jackson Queueing Network," Which aims to minimize queue waiting times at University Covenant Hospital Center by adopting the open Jackson queuing network. The results of these studies provide recommendations for the addition of employees at each point of service facilities to reduce patient waiting time [9]. Besides being implemented in hospital queues, research implements an open Jackson queue network in the Surabaya carnival vehicle queue system [11]. Method Jackson Network Queueing can also be implemented to queuing systems in fields packing goods in a textile company, whereby implementing the Jackson queue network, a longer time in packaging, is 570 seconds faster [14].

Based on some of these studies, it can be shown that implementing the Jackson queue network can minimize the waiting time of individuals in a queue network. So in this study, by implementing an open Jackson queue network model, it is hoped will reduce waiting time in queueing at cardiology outpatient hospital installation.

This study implemented an open Jackson queueing network because the hospital's outpatient installation queue system has an open Jackson queue network characteristic. In this study, the queueing network Jackson will be implemented in 4 workstations, including registration, pre-consultation, and consultation of cardiology poly and pharmacy.

\section{Methods}

\subsection{Data}

The research was conducted at an outpatient installation for BPJS patients in Sidoarjo Hospital, observed in 4 workstations, including registration, cardiology poly preconsultation, cardiology poly consultation, and pharmacy. Research time to check the hospital queue system and data collection was carried out for six working days. Data was collected from Monday, November $16^{\text {th }}$ to Saturday, November $21^{\text {st }}, 2019$.

The data was collected at an outpatient installation by observing the queuing system and recording patients' numbers coming and leaving at four workstations. The number of patients coming and leaving each workstation recorded every time with an interval of 5 minutes, where each point observed for 4 hours from 07.00 to 11.00. Furthermore, the researcher interviewed one of the hospital employees about the queuing system at the hospital.

\subsection{Data Processing}

The steps of research and data processing are presented in the flow chart in Figure 2. 


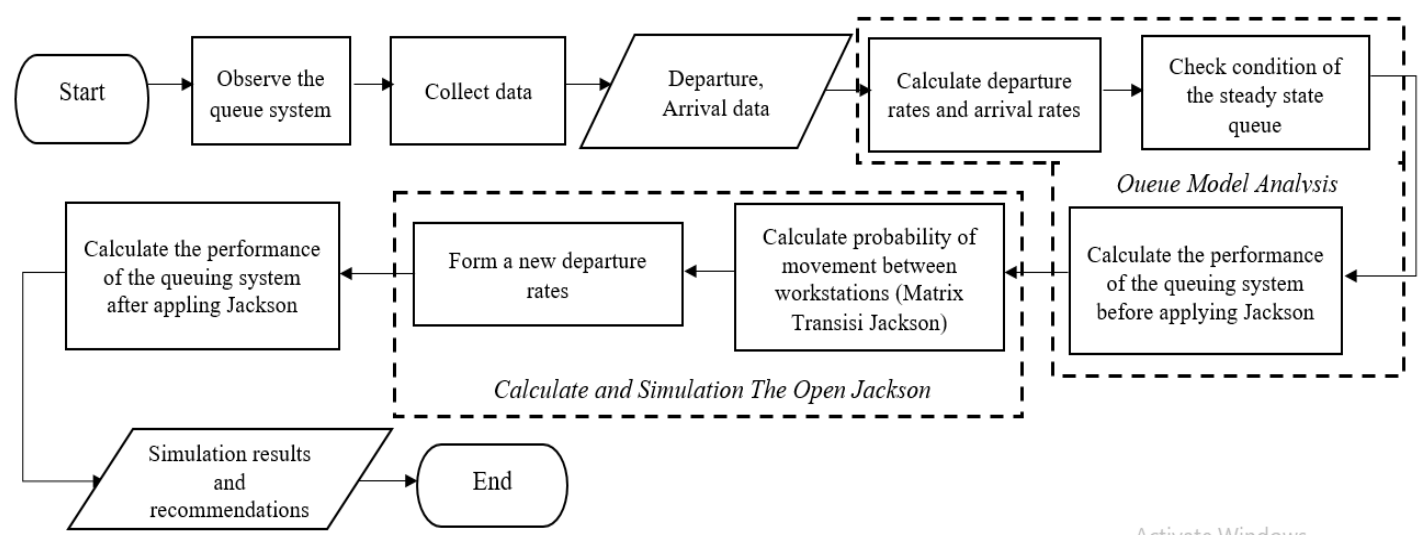

Figure 2. Flowchart of Research and Data Processing

\section{a. Hospital Queue Model Analysis}

1) Calculate the average arrival averages and departure averages

First, calculate the average arrival rate $(\lambda)$ and departure rate $(\mu)$ of each workstation using Equations (1) and (2).

$$
\begin{aligned}
& \lambda=\frac{\text { average of arrival individuals }}{\text { time }} \\
& \mu=\frac{\text { average of departure individuals }}{\text { time }}
\end{aligned}
$$

2) Check the condition of the queue system

Then proceed to check whether the queue system's condition included steady-state or not using Equation (3). Condition steady state $(\rho)$ is the state of the system that does not depend on the initial event and the time elapsed. Condition steady state of $\mathrm{M} / \mathrm{M} / \mathrm{s}$ queuing model with $(s)$ is the number of servants than the system utility,

$$
\rho=\frac{\lambda}{\mu}<s
$$

3) Calculate queuing system performance

The queueing model in this study has the same character as the Queue model (M/M/S): (FCFS $/ \infty / \infty)$, therefore, to calculate queue system performance using Equation (4) to (7).

Queue model (M/M/S): (FCFS/ $/ \infty / \infty)$ is a queueing model with services without capacity limit. This model has the number of employees or server (s) more than one so that a maximum of individuals can be served simultaneously by the server as many as (s). The queuing discipline in this model includes FCFS, where first-come individuals will be first served. In this model, the arrival rates are the number of individuals/units of time $(\lambda)$, and the departure rate is the number of individuals/units of time $(\mu)$ following the Poisson distribution and service time $\left(\frac{1}{\mu}\right)$ following the exponential distribution [15].

Queue performance for queuing model (M/M/S): (FCFS/ $/ \infty)$ is,

$$
\begin{aligned}
& P_{0}=\left\{\left[\sum_{n=0}^{s-1} \frac{(\lambda / \mu)^{n}}{n !}\right]+\frac{(\lambda / \mu)^{s}}{s_{r} !(1-\lambda / s \mu)}\right\}^{-1} \\
& L_{q}=\frac{\lambda \mu(\lambda / \mu)^{s}}{(s-1) !(s \mu-\lambda)} P_{0}
\end{aligned}
$$


$L_{s}=L_{q}+\frac{\lambda}{\mu}$

$W_{s}=\frac{L_{s}}{\lambda}$

where:

$P_{0}=$ probability of no individuals in the queuing system

$L_{q}=$ average number of individuals waiting in a queue (individuals/minutes)

$L_{S}$ =average number of individuals waiting in the queuing system (individuals/minutes)

$W_{S}=$ average waiting time in a queuing system

\section{b. Calculation of Open Jackson Queuing Network}

Some conditions are assumed in the Jackson queuing network; including first Individuals come from outside the queueing network with an arrival rate $\lambda_{i}$ following Poisson distribution and all arrivals are independent. Second, the individual service time of each queue following an exponential distribution. Third, every individual who has been served at the workstation $(i)$ will move to the workstation to $(j)$ with $(P i j)$ probability. Finally, service discipline following FCFS (First Come First Serve) [9].

1) First, make a mathematical model of a linear equation using Equations (8) and (9).

$$
\begin{aligned}
& \lambda_{j}=a_{j}+\sum_{i=1}^{N} \mu_{i} P_{i, j}, 1 \leq i \leq \mathrm{N} \\
& \mu_{i}=\sum_{j=1}^{N} \mu_{i} P_{i, j}, 1 \leq j \leq \mathrm{N}
\end{aligned}
$$

where,

$a_{i} \quad=$ External arrival rate to the workstation $(i)$

$\lambda_{i}=$ Total arrival rate to the workstation $(i)$

$\mu_{i} \quad=$ Total departure rate to the workstation $(i)$

$P_{i, j} \quad=$ probability of individual displacement from the workstation $(i)$ to $(j)$

$\mathrm{N}=$ Total workstation

Make a mathematical model of a linear equation using Equations (8) and (9) of each workstation and based on outpatient patients' network queue in Figure 3. This linear system equation contains three variables.

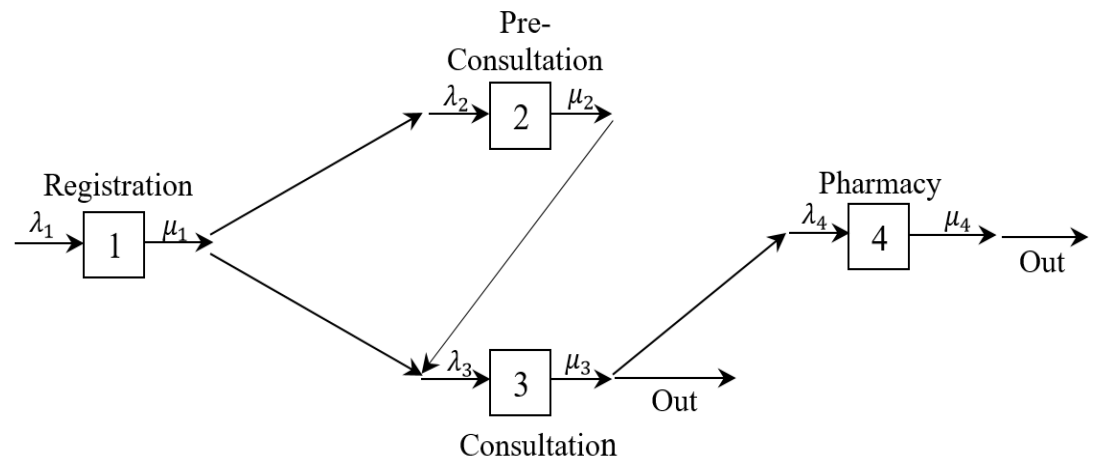

Figure 3. Flowchart of Hospital Queue Network

Queue network diagram schemes formed into linear Equations (8) and (9) illustrate the probability of patient movement.

$$
\begin{aligned}
& \lambda_{1}=a_{1}+0 P_{1,2}+0 P_{1,3}+0 P_{2,3}+0 P_{3,4}+0 P_{3, \text { out }}+\mu_{4} P_{4,1}+0 P_{4, \text { out }} \\
& \lambda_{2}=\mu_{1} P_{1,2}+0 P_{1,3}+0 P_{2,3}+0 P_{3,4}+0 P_{3, \text { out }}+\mu_{4} P_{4,1}+0 P_{4, \text { out }} \\
& \lambda_{3}=0 P_{1,2}+\mu_{1} P_{1,3}+\mu_{2} P_{2,3}+0 P_{3,4}+0 P_{3, \text { out }}+\mu_{4} P_{4,1}+0 P_{4, \text { out }}
\end{aligned}
$$




$$
\begin{aligned}
& \lambda_{4}=0 P_{1,2}+0 P_{1,3}+0 P_{2,3}+\mu_{3} P_{3,4}+0 P_{3, \text { out }}+\mu_{4} P_{4,1}+0 P_{4, \text { out }} \\
& \mu_{1}=\mu_{1} P_{1,2}+\mu_{1} P_{1,3}+0 P_{2,3}+0 P_{3,4}+0 P_{3, \text { out }}+\mu_{4} P_{4,1}+0 P_{4, \text { out }} \\
& \mu_{2}=0 P_{1,2}+0 P_{1,3}+\mu_{2} P_{2,3}+0 P_{3,4}+0 P_{3, \text { out }}+\mu_{4} P_{4,1}+0 P_{4, \text { out }} \\
& \mu_{3}=0 P_{1,2}+0 P_{1,3}+0 P_{2,3}+\mu_{3} P_{3,4}+\mu_{3} P_{3, \text { out }}+\mu_{4} P_{4,1}+0 P_{4, \text { out }} \\
& \mu_{4}=0 P_{1,2}+0 P_{1,3}+0 P_{2,3}+0 P_{3,4}+0 P_{3, \text { out }}+\mu_{4} P_{4,1}+\mu_{4} P_{4, \text { out }}
\end{aligned}
$$

2) The second step is to determine the transition matrix Jackson.

Workstations in the queueing network Jackson form a schematic diagram illustrating the possibility of individual displacement from one workstation to another workstation. Transition matrix Jackson is a matrix that shows the probability of displacement.

The average arrival and departure rates are known based on the data that has been collected so that the value that needs to be sought is $\mathrm{P}$, the probability of patient movement. The equation will be formed into the matrix multiplication $\lambda=\mu P$ then to find the value of the matrix $\mathrm{p}$, the matrix $\mu$ is converted and multiplied by the matrix $(\lambda)$.

3) Finally, a linear equation of the new departure rate is:

$$
\lambda_{j}=\sum_{i=1}^{N} P_{i j} \mu_{i}, 1 \leq i \leq \mathrm{N}
$$

Now that the probability of transfer from the workstation $(i)$ to $(j)$ is known, the next step is to form a mathematical model for the new departure rate. The total waiting time for patients in the queuing system must be faster than before the calculation. The new mathematical model uses the help of equations (10) to (13) and (18).

By the new departure rate value, the performance of the queue system also changes. Hence, it is necessary to check the queue performance's size so that it can be compared with the performance of the queue system before implementing the Jackson queue network.

\section{Result and Discussion}

The data in this study is the total of arrival and departure of patients at each observed workstation with calculation intervals every 5 minutes for 4 hours. In the queuing system, there is a situation called the busy period, where the number of patients has increased higher than the other times. The registration counter has a rush hour from 07.00-08.00, at the pharmacy point has a rush hour from 09.00-10.00, at the cardiology poly pre-consultation has a rush hour from 07.00-08.00, while at the doctor's consultation point has a rush hour 08.00-09.00. Based on data analysis, the arrival and departure rate used for the next calculation step uses the arrival rate at rush hour.

Table 1. Arrival and Departure Rates Every Minute

\begin{tabular}{cccc}
\hline No & Workstation & Arrival Rate $(\lambda)$ & Departure Rate $(\mu)$ \\
\hline 1 & Registration & 2.23056 & 0.91111 \\
2 & Pre-consultation & 0.70833 & 0.37500 \\
3 & Consultation & 0.57778 & 0.31390 \\
4 & Pharmacy & 2.30833 & 0.77500 \\
\hline
\end{tabular}

Source: processing primary data from observation

\subsection{Performance Analysis of The Initial Queue Model}

The hospital queue network system's characteristics follow the Poisson distribution for arrival time during the exponential distribution for the distribution of service time. The applicable service discipline is that patients who come first are first served to apply the 
FCFS (First Come First Served) discipline. In contrast, the capacity of the patient arrival source system is unlimited. Also, the servants who owned all workstations were more than 1. The registration workstation had 4 counters; the pharmacy point had 3 employees, the pre-consultation point in cardiology poly had 2 nurses and had 2 doctors on duty for the consultation point. All workstations are steady-state.

Based on the queuing system's analysis and calculation of the performance size of the queuing model shown by the number of patients waiting in the queuing system and the average number of patients waiting in the queuing system, the results of performance for each workstation are listed in table 2 .

Table 2. Initial Queue Model Performance

\begin{tabular}{clccc}
\hline No & Workstation & Lq & Ls & Ws \\
\hline 1 & Registration & 2.98811 & 5.43629 & 2.43718 \\
2 & Pre-consultation & 15.5968 & 17.4857 & 24.6857 \\
3 & Consultation & 10.19411 & 12.03482 & 20.82949 \\
4 & Pharmacy & 36.62870 & 139.60720 & 60.47965 \\
\hline \multicolumn{3}{c}{ Total } & & 108.432 \\
\hline
\end{tabular}

Based on the calculation of the performance initial queuing model above, it can be concluded that the average time spent by a patient to conduct a health check at the cardiology polyclinic of the hospital is 108 minutes/patient.

\subsection{Application of the Jackson Queue Network}

\section{a. Probability of movement between workstations}

The first step of Jackson's calculation is to calculate the probability of movement using Equation (10) to Equation (17), which describes individuals' movement between workstations. To make it easier to find probability values, the linear equation is converted into a matrix.

$$
\begin{aligned}
& \left(\begin{array}{l}
\lambda_{2} \\
\lambda_{3} \\
\lambda_{4} \\
\mu_{1} \\
\mu_{2} \\
\mu_{3} \\
\mu_{4}
\end{array}\right)=\left(\begin{array}{ccccccc}
\mu_{1} & 0 & 0 & 0 & 0 & 0 & 0 \\
0 & \mu_{1} & \mu_{2} & 0 & 0 & 0 & 0 \\
0 & 0 & 0 & \mu_{3} & 0 & 0 & 0 \\
\mu_{1} & \mu_{1} & 0 & 0 & 0 & 0 & 0 \\
0 & 0 & \mu_{2} & 0 & 0 & 0 & 0 \\
0 & 0 & 0 & \mu_{3} & \mu_{3} & 0 & 0 \\
0 & 0 & 0 & 0 & 0 & \mu_{4} & \mu_{4}
\end{array}\right)=\left(\begin{array}{c}
P_{1,2} \\
P_{1,3} \\
P_{2,3} \\
P_{3,4} \\
P_{3, \text { out }} \\
P_{4,1} \\
P_{4, \text { out }}
\end{array}\right) \\
& \left(\begin{array}{l}
0.708 \\
0.578 \\
2.308 \\
0.911 \\
0.375 \\
0.314 \\
0.775
\end{array}\right)=\left(\begin{array}{ccccccc}
0.911 & 0 & 0 & 0 & 0 & 0 & 0 \\
0 & 0.911 & 0.375 & 0 & 0 & 0 & 0 \\
0 & 0 & 0 & 0.314 & 0 & 0 & 0 \\
0.911 & 0.911 & 0 & 0 & 0 & 0 & 0 \\
0 & 0 & 0.375 & 0 & 0 & 0 & 0 \\
0 & 0 & 0 & 0.314 & 0.314 & 0 & 0 \\
0 & 0 & 0 & 0 & 0 & 0.775 & 0.775
\end{array}\right)=\left(\begin{array}{c}
P_{1,2} \\
P_{1,3} \\
P_{2,3} \\
P_{3,4} \\
P_{3, \text { out }} \\
P_{4,1} \\
P_{4, \text { out }}
\end{array}\right) \\
& \left(\begin{array}{c}
P_{1,2} \\
P_{1,3} \\
P_{2,3} \\
P_{3,4} \\
P_{3, \text { out }} \\
P_{4,1} \\
P_{4, \text { out }}
\end{array}\right)=\left(\begin{array}{ccccccc}
0.911 & 0 & 0 & 0 & 0 & 0 & 0 \\
0 & 0.911 & 0.375 & 0 & 0 & 0 & 0 \\
0 & 0 & 0 & 0.314 & 0 & 0 & 0 \\
0.911 & 0.911 & 0 & 0 & 0 & 0 & 0 \\
0 & 0 & 0.375 & 0 & 0 & 0 & 0 \\
0 & 0 & 0 & 0.314 & 0.314 & 0 & 0 \\
0 & 0 & 0 & 0 & 0 & 0.775 & 0.775
\end{array}\right)^{-1}\left(\begin{array}{c}
0.708 \\
0.578 \\
2.308 \\
0.911 \\
0.375 \\
0.314 \\
0.775
\end{array}\right)=\left(\begin{array}{c}
0.78 \\
0.22 \\
1 \\
0.99 \\
0.01 \\
0.5 \\
0.5
\end{array}\right)
\end{aligned}
$$


The determinant of matrix $\mu$ is 0 , so that the next step is to find the inverse value using the Moore-Penrose pseudoinverse [16].

Based on the result of the calculation, the probability of the patient moving from registration (point 1 ) to pre-consultation (point 2 ) is 0.78 , while if going to the consultation (point 3 ), the probability is 0.22 . The probability value of pre-consultation to the consultation is 1 . The probability of consultation to the pharmacy (point 4 ) is 0.99 while going straight out of the consultation is 0.01 . The probability value is used to calculate the new $\mu$ departure rate.

\section{b. New Departure Rate}

Implementing the Jackson queue network is to minimize patient waiting time at each workstation from the queueing network. To minimize patient waiting time is increasing the number of patients who leave the service. The arrival of individuals from outside or inside the system cannot be limited, but the number of individual leave from the queuing system can be increased so that the queues in the system can be reduced. The solution is by calculating the new $\mu$ departure rate from each workstation using a linear equation from Equations (10) to (13). The linear equation is converted into a matrix to simplify the calculation.

$$
\begin{aligned}
\left(\begin{array}{cccc}
0 & 0 & 0 & P_{4,1} \\
P_{1,2} & 0 & 0 & 0 \\
P_{1,3} & P_{2,3} & 0 & 0 \\
0 & 0 & P_{3,4} & 0
\end{array}\right)\left(\begin{array}{l}
\mu_{1} \\
\mu_{2} \\
\mu_{3} \\
\mu_{4}
\end{array}\right)=\left(\begin{array}{l}
\lambda_{1} \\
\lambda_{2} \\
\lambda_{3} \\
\lambda_{4}
\end{array}\right) \\
\left(\begin{array}{l}
\mu_{1} \\
\mu_{2} \\
\mu_{3} \\
\mu_{4}
\end{array}\right)=\left(\begin{array}{l}
3.662 \\
2.835 \\
3.649 \\
7.299
\end{array}\right)
\end{aligned}
$$

Based on the new departure rate results, the value of the new departure rate $(\mu)$ from registration is 3.662 if rounded up to 4 . For pre-consultation departure rate change to 2.835 rounded up to 3 while for consultation workstation to 3.649 rounded up to 4 and for pharmacy departure rate rounded down to 7 employees.

The new departure rate value explains that for workstations to produce as many patients as the new departure rate, the number of employees per workstation must also be as much as the new departure rate. Therefore, it needs to add employees for the registration workstation are become 4 servers. Cardiology poly is recommended to have 3 nurses and 4 doctors, while for pharmacy have 7 employees.

\subsection{Simulation and Discussion}

The results of implementing the Jackson queue network is recommended to add servers or employees. The registration workstation is recommended to have 4 servers. Cardiology poly is recommended to have 3 nurses and 4 doctors, while for pharmacy have 7 employees. Base on these recommendations, the performance of the new model queue is shown in table 3.

\begin{tabular}{|c|c|c|c|c|c|}
\hline No & Workstation & $\begin{array}{c}\text { Employees / } \\
\text { Servers }\end{array}$ & $\mathrm{Lq}$ & Ls & Ws \\
\hline 1 & Registration & 4 & 1.68829 & 4.73417 & 2.32241 \\
\hline 2 & Pre-consultation & 3 & 0.90705 & 2.91496 & 4.21524 \\
\hline 3 & Consultation & 4 & 0.22489 & 2.33356 & 4.13885 \\
\hline 4 & Pharmacy & 7 & 0.26650 & 2.10115 & 0.98025 \\
\hline
\end{tabular}

Table 3. Performance of The New Model Queue

Source: Author's Calculation 
The queuing system's performance after implementing an open Jackson queue network is simulated in Figure 4 so that the queuing system can be easily understood.

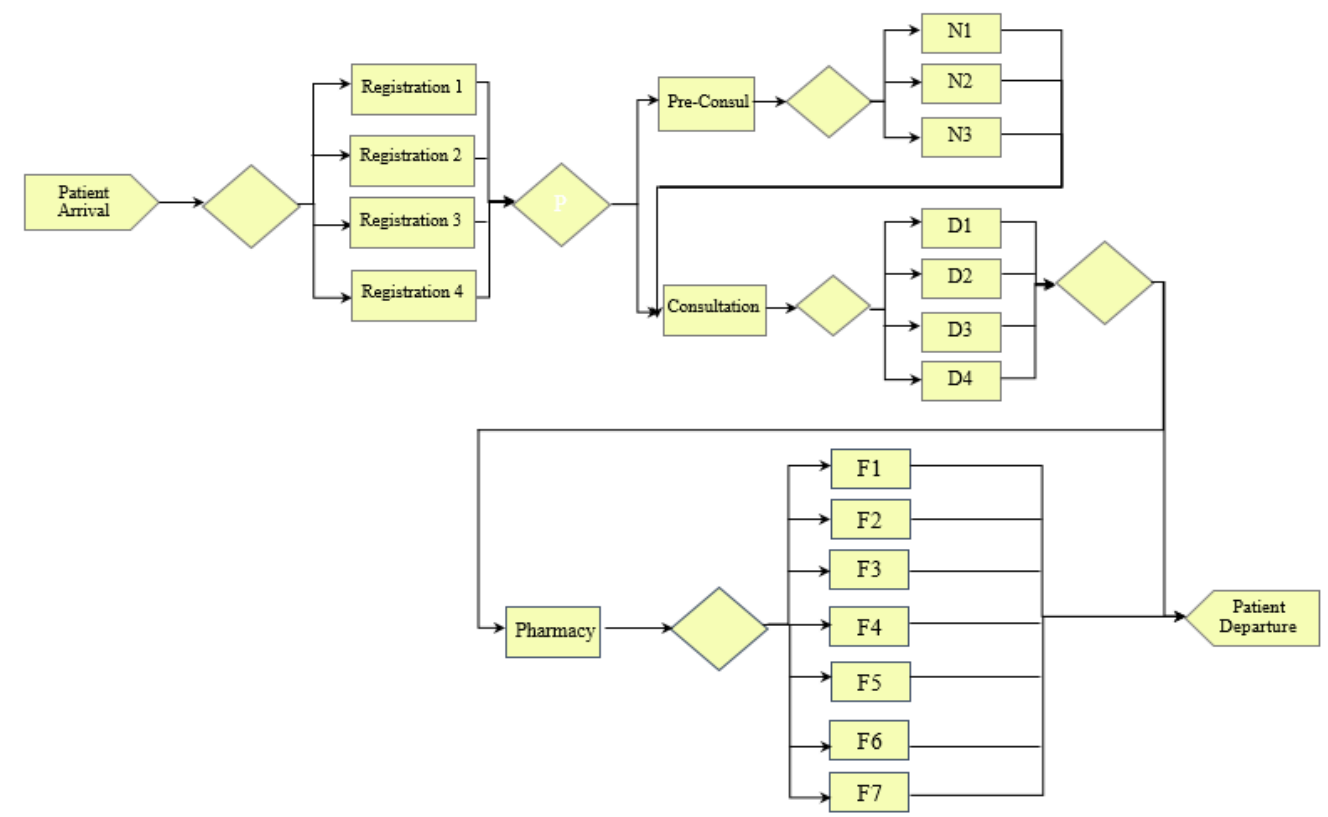

Figure 4. Simulation Results

By adding the number of employees based on the Jackson queue network's recommendation, it was obtained that the total length of waiting time was approximately 12 minutes. So, it can reduce waiting times in the queueing system that was initially 108 minutes/patient.

In this case study, a queueing model was produced that could reduce waiting times. Still, it was not easy for hospitals to be able to implement the recommendations given by researchers. Because of the addition of human resources will undoubtedly incur costs as well. For the next research, it should not only optimize through the queue model but also conduct a study related to the costs incurred as a result of the recommendation of the model compared to the economic benefits obtained (cost and benefit ratio analysis). So that the optimization will be more effectives and its recommendations can be applied.

\section{Conclusions}

Implementing an open Jackson queue network was recommended to add employees to each workstation. The registration workstation must have four servers, a poly cardiology workstation had three nurses, and four doctors, while for pharmacy, had seven employees. By adding the number of employees following the recommendations, the patient's total time in the queuing system is approximately 12 minutes per patient if this recommendation is implemented in the Sidoarjo Hospital. So, it can reduce waiting times in the queueing system that was initially 108 minutes/patient.

\section{References}

[1] WHO, "Cardivascular Disease," WHO, 2016. [Online]. Available: origin.who.int/cardivascular_disease/en/.

[2] A. Rangkuti, 7 Model Riset Operasi dan Aplikasinya. Surabaya: Firstbox Media, 2013. 
[3] Aminuddin, Prinsip-Prinsip Riset Operasi. Jakarta: Erlangga, 2005.

[4] S. A. Mangkona and I. Murdifin, "Implementation of Queue Model for Measuring the Effectiveness of Suzuki Car Maintenance," World J. Bus. Manag., vol. 3, no. June 2017, pp. 55-66, 2017.

[5] H. A. Taha, "Operations Research," 8th ed., New York: Pearson Education, 2007.

[6] C. Skautis and T. Boyle, "Human Enabled Health Care," CA Emerg. Technol., pp. 110, 2009.

[7] F. Baskett and S. Unzvers, "Open, Closed, and Mixed Networks of Queues with Different Classes of Customers Open, Closed, and Mixed Networks of Queues with Different Classes of Customers," J. Assoc. Comput. Mach., vol. 22, no. April, pp. 248-260, 1975.

[8] W. J. Gordon and G. F. Newell, "Closed Queuing Systems with Exponential Servers," Oper. Res., vol. 15, pp. 254-265, 1967.

[9] A. E. Owoloko, O. Adeleke, and S. O. Edeki, "On the Application of the Open Jackson Queuing Network," Glob. J. Pure Appl. Math., vol. 11, no. August 2016, pp. 2299-2313, 2015.

[10] A. U. Amri and I. Endrayanto, "Aplikasi Model Jaringan Antrian Jackson Terbuka dengan Studi Kasus di Unit Gawat Darurat," Universitas Gajah Mada, 2018.

[11] S. W. Djatmiko and L. M. W Cahya, "Analisis Sistem Antrian Menggunakan Metode Jackson pada Wahana Outdoor Suroboyo Carniva," Semin. Nas. Sains dan Teknol. $U M J$, no. November, pp. 1-9, 2016.

[12] K. Sigman, "The Stability of Open Queueing Network," Stoch. Process. a Their Appl., vol. 35, pp. 11-25, 1990.

[13] P. J. Burke, "The Dependence of Service in Tandem M/M/s Queues," Oper. Res., vol. 17, pp. 754-755, 1969.

[14] L. Ratnasari, Y. Widiatama, and R. N. Dewanti, "Analisa Antrian Pengerjaan Benang Heat Technology dengan Metode Jackson Network di PT. Kurabo Manunggal Textil Industries," Teknologi, vol. 1, no. Maret 2018, pp. 18-26, 2018.

[15] H. A. Taha, "Riset Operasi," 5th ed., Jakarta: Binarupa Aksara, 1997.

[16] J. C. A. Barata and M. S. Hussein, "The Moore-Penrose Pseudoinverse. A Tutorial Review of the Theory," pp. 1-23, 2011. 